\title{
Attitudes, Poverty and Agency in Russia and Ukraine
}

\author{
Ann-Mari Sätre och Ildikó Asztalos Morell (red.) \\ Oxfordshire: Routledge 2016 \\ 160 sidor. ISBN 9781138957640
}

Recenserad av Ekaterina Tarasova [PhD, lektor, Södertörns Universitet, ekaterina. tarasova@sh.se]

Redigerad av Ann-Mari Sätre och Ildikó Asztalos Morell, boken Atittudes, Poverty and Agency in Russia and Ukraine presenterar sju studier om fattigdom i Ryssland och Ukraina. Författarna syftar till att analysera kontinuiteter rörande fattigdomsfrågor som kvarstår från sovjettiden. Dessa två länder är utvalda eftersom de har delvis likartad och delvis annorlunda historiska och politiska utvecklingar efter upplösningen av Sovjetunionen medan de har en del gemensam historia och kultur. Denna samling av kapitlen publicerades tillsammans tidigare som tidskriftsartiklar i en specialutgåva.

Boken tar upp fattigdomsfrågor ur perspektivet av attityder mot fattigdom och de fattiga, politik för fattigdomsminskning och överlevnadsstrategier för de fattiga. En sådan bred uppställning i boken gör det möjligt att lyfta fram olika dimensioner och aspekter av fattigdomsfrågor. Inte minst diskutera olika grupper av fattiga. Studierna berör sådana grupper av fattiga som fattiga familjer, hemlösa samt singelmän. Studierna visar att diskussioner om fattigdom oftast konstrueras genom att skilja åt de som förtjänar och icke förtjänar stöd. Flera kapitel beaktar på fattigdom och fattiga i små städer. Kvinnans roll för den sociala sektorn tas upp i flera kapitel eftersom det finns en särskild problematik och viss kontinuitet i denna aspekt av fattigdomsminskning. Sätre beskriver dessa kontinuiteter som kvinnans ansvar för socialpolitik, deras förutsättningar på arbetsmarknaden och inkomster i motsats till männen samt entreprenörsförmåga att hantera fattigdom.

Boken består av sju kapitel med kort inledning av Ann-Mari Sätre. I det andra kapitlet granskar Varyzgina och Kay uppfattningar av fattigdom i en liten stad i Ryssland. De hävdar att uppfattningar om fattigdom delas inom olika samhällssektorer. De upptäcker att fattigdom diskuteras som sänkt konsumtion, olycka, sjukdom, fara och stigma. Uppfattningarna är av betydelse för hur människor relaterar till rätten till stöd. I det tredje kapitlet diskuterar Ryabchuk social konstruktion av hemlöshet, moraliska utvärderingar av hemlösa och strukturella orsaker till hemlöshet, som 


\section{EKATERINA TARASOVA}

bostadsmarknaden och osäkra bostadssituationer samt arbetslöshet i Ukraina. Bland annat diskuteras hemlöshet i relation till den kapitalistiska arbetsmarknaden. Det nästa kapitlet skriven av Sätre, Soldatkin och Varyzgina ger en översikt över strategier och sätt att hantera fattigdom. De visar att sådana strategier som egna medel, horisontell rörlighet (förändring av jobb eller yrke), beroende av materiellt stöd från vänner och släktingar, mobilisering uppåt med hjälp av externa resurser användes. Dessa strategier kan kombineras.

I det femte kapitlet examinerar Asztalos Morell och Tiurikova livsstrategier av arbetande ryska singelmän vid ett senare skede av arbetslivet med låg inkomst medan de är verksamma i informell ekonomi. Genom ett sådant fokus utför studien en analys av alternativa vägar av maskuliniteter. Det sjätte kapitlet presenterar en undersökning av Kostiuchenko och Söderbaum som behandlar den ukrainska elitens insatser att minska fattigdom, bland annat deras filantropi. Författarna undersöker om eliter väljer att bedriva filantropi med fokus på ursprunget till sociala problem eller mer kortsiktig välgörenhet.

I det sjunde kapitlet analyserar Sätre "hur socialpolitiken ger möjligheter till fattiga människor att förbättra sina livssituationer” och vilka problem som uppstår med genomförande av den sociala politiken. Hon belyser även hur kvinnor som är anställda i den sociala sektorn hanterar dessa problem. I det sista kapitlet undersöker Ivashinenko attityder mot fattigdom i en liten rysk stad med fokus på samhällets engagemang. Hon pekar på att icke-statliga aktörer också är viktiga för att minska fattigdomen, inte bara de statliga. Ivashinenko pekar specifikt på nätverk av släktingar som är en viktig resurs för social trygghet.

Flera kapitel belyser hur informella institutioner och ekonomi spelar viktiga roller i överlevnas strategier av de fattiga samt strategier av de som är anställda i den sociala sektorn. Med hänsyn till i vilken utsträckning informella institutioner och ekonomi är sammanflätade i post-sovjetiska samhällen uppskattas forskningen som uppmärksammar både formella och informella institutioner och praktiker.

Eftersom varje kapitel är en separat undersökning, har författare möjlighet att gå djupt i diskussioner kring de aspekter som de studerar. Samtidigt, även om det syns att författarna pratar med varandra i vissa aspekter, begränsar detta format möjligheter till en stor diskussion mellan kapitlen. Varje kapitel diskuterar antingen Ryssland eller Ukraina. Det skulle vara intressant att se ett till kapitel där slutsatser från varje studie behandlas tillsammans. I synnerhet skulle det vara intressant att veta mer om författarnas tänker kring kontinuiteter i avseende till fattigdomsfrågor från sovjettiden och likheter mellan Ryssland och Ukraina. Dessutom kan man undra hur slutsatserna i studierna kan relateras till andra post-sovjetiska länder.

Sammanfattningsvis, boken presenterar omfattande diskussioner av attityder mot fattigdom, politik som syftar till fattigdomsminskning och överlevnadsstrategier i Ryssland och Ukraina. Den rekommenderas att läsas för forskare såväl som allmänheten som intresserar sig för fattigdomsfrågor i Ryssland och Ukraina samt även för de med generellt intresse för socialpolitik i post-sovjetiska länder. 